Editorial

\title{
On Rockets, Economics and the Reform of Higher Education
}

Higher Education Policy (2003) 16, 385-388. doi:10.1057/palgrave.hep.8300037

In this issue, Higher Education Policy focuses on the People's Republic of China, although not exclusively so since it also includes articles on Japan and Mongolia. In the Forum section, we reach out further a-field to Saudi Arabia and to Bangladesh.

\section{Rockets and Reform: the Symbolic and the Concrete}

Recent events have, of course, underlined in a spectacular manner, what more subtle observers have long noted - namely, the return of China as one of the World's major powers on the international scene. Of course, China's claim to be Number Three in the Cosmomauts' Club brings this home in a way few can deny. Nor is precedent lacking. The galvanizing effect that the launching in 1957 of the first Russian Sputnik had upon higher education in the United States is a matter of record. Less than a year later, the National Defense (Education) Act of 1958 put in train a whole host of reforms, ranging from government loans to study at college, to graduate fellowships and very particularly in the areas of Mathematics, the Sciences and the learning of foreign languages. Nor was the mobilization of national talent limited to higher education. Elementary and secondary schools were also involved. Very special attention was paid to students 'superior academically', 'who indicate a desire to teach in elementary and secondary schools'. (http://ishi.lib.berkeley.edu/cshe/ ndea/ndea.html).

Clearly, then as now, the symbolism of achievement in rocketry has echoes far beyond the realms of the military or the corridors of space administration. The question remains, however, who will be galvanized by the Chinese achievement? And what form such girding up of loins will take?

\section{Regional Mobilization}

Even before the lift off of Shenzhou V on October 15th, another kind of mobilization has long been evident in the region and the question it poses is no less significant for China. It has to do with that development some view as 
'Globalization', others as the 'internationalization' of higher education. The Asia Pacific region may not be the heartland of either of these trends. It is, however, precisely there that they are developing the most rapidly and very particularly so since it is on this region that the designs and ambitions of 'exporting systems' of higher education - the United States, Australia and to a lesser degree, the United Kingdom - are concentrating their efforts. The establishment of overseas branch campuses appears to be more advanced here than elsewhere. And such initiatives, very real pointers though they are towards the 'commodification' of education, are for that very reason also pointers to the importance that China itself has for the hawkers of e-learning, the sellers of e-business and the practitioners of virtual learning.

Now the basic question that China faces today is not whether its space programme is to develop further, although in all likelihood it will do so. Nor even whether the very real achievement it shows will embrace other sectors of China's economy and society. It is rather whether that Nation is to rely on its own efforts to maintain economic progress or whether it will call upon the facilities and provision already available abroad and present in other systems to develop a higher education base sufficient to sustain its path towards what many see in the near future as being the world's major manufacturing economy. There is always a third possibility, namely to combine the two - in effect, to rely on home-based facilities for those skills found at mid-range management and technician level, while drawing on external systems to develop those key competencies for innovation and research that require time and long-term investment as conditions for their advance.

\section{Leap Frogging: A Strategy Both Old and New}

This strategy - of relying on facilities provided by other systems irrespective of whether they are to be located in the country, or to be transmitted from outside - is not greatly novel, although its application in China may well turn out to be so. This strategy is often known as 'leap frogging'. Its validity as a historical process found a very real expression in Germany's innovative advance over Britain during the second industrial revolution - and very precisely, the advance the former gained over the latter in the domain of electro-chemicals in the 1880s. One can, of course, argue that in this form - as a historic process - 'leap frogging' was more in the nature of a happy outcome than a strategy introduced with a shared coherence of purpose, goal and intent.

The strategy of leap frogging as a planned national goal stands as a more recent development. Implicitly, it lay at the heart of higher education planning in the developing economies and very particularly, during the early days of post-Colonial growth of higher education in Africa, although one cannot avoid 
the conclusion that more often than not, such a strategy served as a terrible lesson: namely, to demonstrate that official intention does not always imply capacity within the Nation to fulfil it. Still, there are other examples, which turn upon the notion of 'leap frogging' as a developmental strategy. The most recent among them has emerged in a World Bank initiative in Africa.

The creation of an African Virtual University stands as another variation upon the strategy of leap frogging. It rests upon a very different basic concept than its predecessors that, by and large, applied within the political boundaries of States. As a principal component brought to bear on 'leap frogging', virtual learning injects into that strategy a dimension that is novel - to wit, the concept of complementarity. Complementarity involves the employment of resources and facilities in one system to complement — or to make up — the shortcomings in another and to do so through the use of distance teaching, multi-media methods of training and the injection of information and communications technology to transfrontier education.

\section{Separation of Intent and Capacity}

In effect, distance teaching and virtual universities have the potential to give a new impetus to the time-honoured strategy of leap frogging for the simple reason that not only do they separate learning from the constraints of time, presence - or for that matter - of age but they also separate intention from capacity. That one region has the intention does not mean that its intention is limited by its capacity to organize or to develop the structures and provision usually associated with raising the level of knowledge among those among its citizens who demand it. Rather the capacity to deliver that implies the investment in human and technical resources has already been made, and thus the capacity to disseminate or to provide no longer resides with the consumer. Capacity resides with the provider, while intention or the goal to speed up economic development resides with those governing those who consume.

\section{Perspectives on Change in the PRC}

As many of the articles in this issue show, higher education in the PRC, like its counteparts elsewhere, is in a state of flux and this in various forms. Luo Siming examines changes in the degree system in China while Li Shu-wan traces the effects of industrial change upon the governance structure of one 'branch' of higher education given over to textile manufacturing. Mark Bray traces the fortunes of the higher education system in Macau as it cut loose from the Portuguese presence and re-integrated into mainland China. Guijan Gao's account of what appears to be China's equivalent of extension courses, 
students following university programmes while not being officially enrolled in mainline institutions of higher education casts light on what to outsiders comes as a little known aspect of that Republic's higher learning. It is all the more interesting precisely because it illustrates with particular clarity the existence of demand that, if recognized officially, is nevertheless catered for by semiprivate agencies, groups or individuals. As such, the 'Self-taught Higher Education Examination' provides further evidence for those 'providers' and organizations outside the PRC of a sizeable market inside.

Finally, two other articles complete our tour d'horizon, one analyzing institutional reform in Mongola by two British consultants, Hall and Thomas and a second by Wanatabe, which analyses the transition from higher education to the workplace by graduates from Japan's Four Year Colleges.

Guy Neave 